OPEN ACCESS

Edited by:

Sherry Shiqian Gao,

The University of Hong Kong,

Hong Kong

Reviewed by:

Denis Bourgeois,

Université Claude Bernard Lyon

1, France

Santosh Pandit,

Chalmers University of

Technology, Sweden

*Correspondence:

Monika Astasov-Frauenhoffer m.astasov-frauenhoffer@unibas.ch

Specialty section

This article was submitted to

Preventive Dentistry,

a section of the journal

Frontiers in Oral Health

Received: 04 March 2021 Accepted: 04 June 2021 Published: 14 July 2021

Citation:

Steiger J, Braissant O, Waltimo T and Astasov-Frauenhoffer M (2021)

Efficacy of Experimental Mouth Rinses on Caries-Related Biofilms in vitro.

Front. Oral. Health 2:676028. doi: 10.3389/froh.2021.676028

\section{Efficacy of Experimental Mouth Rinses on Caries-Related Biofilms in vitro}

\author{
Josiana Steiger ${ }^{1}$, Olivier Braissant ${ }^{2}$, Tuomas Waltimo ${ }^{1}$ and Monika Astasov-Frauenhoffer ${ }^{3 *}$ \\ ${ }^{1}$ Clinic for Oral Health \& Medicine, University Center for Dental Medicine Basel UZB University of Basel, Basel, Switzerland, \\ ${ }^{2}$ Department of Biomedical Engineering (DBE), Center of Biomechanics and Biocalorimetry, University of Basel, Allschwil, \\ Switzerland, ${ }^{3}$ Department Research, University Center for Dental Medicine Basel UZB University of Basel, Basel, Switzerland
}

This study assessed the efficacy of tin and Polyethylenglycol (PEG-3) tallow aminopropylamine in different concentrations on Streptococcus mutans (S. mutans) biofilms to establish a new screening process for different antimicrobial agents and to gain more information on the antibacterial effects of these agents on cariogenic biofilms. Isothermal microcalorimetry (IMC) was used to determine differences in two growth parameters: lag time and growth rate; additionally, reduction in active biofilms was calculated. Experimental mouth rinses with 400 and 800 ppm tin derived from stannous fluoride $\left(\mathrm{SnF}_{2}\right)$ revealed results (43.4 and $49.9 \%$ active biofilm reduction, respectively) similar to meridol mouth rinse (400 ppm tin combined with 1,567 ppm PEG-3 tallow aminopropylamine; 55.3\% active biofilm reduction) ( $p>0.05)$, while no growth of $S$. mutans biofilms was detected during $72 \mathrm{~h}$ for samples treated with an experimental rinse containing 1,600 ppm tin (100\% active biofilm reduction). Only the highest concentration (12,536 ppm) of rinses containing PEG-3 tallow aminopropylamine derived from amine fluoride (AmF) revealed comparable results to meridol (57.5\% reduction in active biofilm). Lower concentrations of PEG-3 tallow aminopropylamine showed reductions of $16.9 \%$ for 3,134 ppm and 33.5\% for 6,268 ppm. Maximum growth rate was significantly lower for all the samples containing $\mathrm{SnF}_{2}$ than for the samples containing control biofilms ( $p<0.05$ ); no differences were found between the control and all the PEG-3 tallow aminopropylamine $(p>0.05)$. The growth parameters showed high reproducibility rates within the treated groups of biofilms and for the controls; thus, the screening method provided reliable results.

Keywords: caries, biofilm, antimicrobial, isothermal microcalorimetry, amine fluoride, stannous fluoride, PEG-3 tallow aminopropylamine

\section{INTRODUCTION}

The oral microflora represents the complex community and cohabits of up to 1,000 different bacterial species [1-4]. Most of the microorganisms favor colonization and adherence on surfaces forming biofilms whenever possible [5-7]. Caries is still a frequently occurring oral health issue in the Global Burden of Disease 2015 study $[8,9]$. It has been known for a long time that the group of mutans streptococci and especially, Streptococcus mutans is the specific pathogen that causes caries. However, more important than one key pathogen is the environment that influences the homeostasis of 
the biofilm. In healthy conditions, demineralization and remineralization of the tooth surface are in balance and no irreversible defect occurs. Through the consumption of a carbohydrate-rich diet and/or too little neutralizing saliva, the environment can become more acidic due to the metabolic products of the bacteria. Thus, the balance is not maintained and aciduric and acidogenic bacteria, such as $S$. mutans and Lactobacilli, gain predominance and accelerate the demineralization, leading to dysbiosis of the microbiota [7, 10-12].

Associations between oral and general health make oral hygiene indispensable. Although tooth brushing is very important to mechanically remove the biofilm, antimicrobial agents used in oral care products like mouth rinses are also very important to protect against the progression of dental caries. Fluorides, in addition to chlorhexidine, cetylpyridinium chloride (CPC), peroxide/perborates, essential oils (EOs), triclosan, delmopinol, and sanguinarine, are occurring agents in mouthwashes $[13,14]$.

This study focused on the inorganic compound tin derived from stannous fluoride $\left(\mathrm{SnF}_{2}\right)$, with its antimicrobial and cariostatic characteristics, and the organic compound of amine fluoride (AmF) PEG-3 tallow aminopropylamine, which can reduce the adherence of bacteria leading to plaque formation and may also influence the diffusion through the cariesaffected enamel [15]. Different studies have shown that a $S$. mutans biofilm treated with AmF leads to a reduction in growth [16], while the antibacterial properties of PEG-3 tallow aminopropylamine, known to act as a surfactant in different kinds of toothpaste, have been assessed to reveal a reduction in vitality for periopathogenic and cariogenic species [17].

Isothermal microcalorimetry (IMC) is a highly sensitive culture-based method that allows the measurement of heat generated by all the microbial activities within the biofilm without disturbing its structure. It allows bacteria to replicate on a suitable culture medium, resulting in an exponential increase in the heat production rate that can be recorded in real time by IMC (i.e., heat flow curve). The main advantage of this method in biofilm research is the opportunity to study them as entities as shown previously [18]. Over the last decade, the method has become more widely used in antimicrobial testing in various fields of medicine [19-22].

This study aimed to use IMC to assess the efficacy of tin and PEG-3 tallow aminopropylamine in different concentrations on $S$. mutans biofilms to establish a new screening process for different antimicrobial agents and to gain more information on the antibacterial effects of these agents on cariogenic biofilms; the antibacterial effect of fluoride was not considered. The null hypothesis was that both antimicrobial agents reveal similar efficacy.

\section{MATERIALS AND METHODS}

\section{Biofilm Formation and Treatment}

Ten $\mu$ l of S. mutans (ATCC ${ }^{\circledR} 25175$ ) stock solution was spread on a Columbia blood agar plate (BBL Columbia Agar Base; $\mathrm{BD}$, Allschwil, Switzerland) and incubated for $48 \mathrm{~h}$ at $37^{\circ} \mathrm{C}$. Thereafter, one colony was picked and added to $25 \mathrm{ml}$ of Todd Hewitt $(\mathrm{TH})$ media (Bacto Todd Hewitt broth; BD, Allschwil, Switzerland) supplemented with $0.5 \%$ sucrose $[\mathrm{D}(+)$ sucrose; Fluka, Buchs, Switzerland]. The culture was incubated for $22 \mathrm{~h}$ at $37^{\circ} \mathrm{C}$. Then, the bacteria were harvested by centrifugation $(8,500$ rpm, 5 min, RT; Sigma 4-16KS, Kuhner, Basel, Switzerland) and resuspended in simulated body fluid (SBF; [23]) supplemented with $10 \% \mathrm{TH}$ medium and $1 \%$ sucrose. Meanwhile, $5 \mathrm{~mm}$ glass disks (Biosystems Switzerland AG, Muttenz, Switzerland) were coated with sterile pooled saliva mixture for $15 \mathrm{~min}$ (described in detail in Astasov-Frauenhoffer et al. [24]) and placed in 24well plates (Sarstedt AG, Sevelen, Switzerland), $1 \mathrm{ml}$ of bacterial suspension and $0.5 \mathrm{ml}$ of $\mathrm{TH}$ medium were added to each well, and the disks were incubated for $24 \mathrm{~h}$ at $37^{\circ} \mathrm{C}$.

After $24 \mathrm{~h}$, the disks with biofilms were dipped $\mathrm{x} 3$ in $0.9 \%$ $\mathrm{NaCl}$ (Merck, Zug, Switzerland) and then placed for $30 \mathrm{~s}$ in $50 \% \mathrm{v} / \mathrm{v}$ mouth rinse solutions (Table 1) and placed in $0.9 \%$ $\mathrm{NaCl}$. Biofilms exposed to $0.9 \% \mathrm{NaCl}$ for $30 \mathrm{~s}$ served as untreated growth controls. Each set consisted of five replicates, and experiments were repeated three times altogether.

\section{Isothermal Microcalorimetry}

Columbia blood agar was prepared, and treated biofilms and untreated controls were placed on the agar with the biofilm facing the agar to monitor the microbial metabolic activity left in the samples. The IMC ampoules were closed in aerobic conditions and placed in TAM 48 instrument (TA Instruments; New Castle, Delaware, USA) where the metabolic activity of the biofilms was recorded at $37^{\circ} \mathrm{C}$ for up to $72 \mathrm{~h}$. Samples that now reveal any growth during that time period were also assessed over 7 days.

The heat flow data obtained over time were analyzed for growth rate $(1 / \mathrm{h})$ and lag time $(\mathrm{h})$ by fitting the heat over time curve (i.e., resulting from the integration of the heat flow

TABLE 1 | One marketed mouth rinse and six experimental mouth rinses used in this study based on their major antimicrobial agent and their concentrations.

\begin{tabular}{|c|c|c|c|c|c|c|c|}
\hline \multirow[t]{2}{*}{ Mouth rinse type } & \multirow{2}{*}{$\begin{array}{l}\text { Marketed rinse } \\
\text { Meridol }\end{array}$} & \multicolumn{6}{|c|}{ Experimental rinses } \\
\hline & & 1 & 2 & 3 & 4 & 5 & 6 \\
\hline Main antibacterial agent & $\begin{array}{l}\text { Tin/ } \\
\text { PEG-3 tallow } \\
\text { aminopropylamine }\end{array}$ & Tin & Tin & Tin & $\begin{array}{l}\text { PEG-3 tallow } \\
\text { aminopropylamine }\end{array}$ & $\begin{array}{l}\text { PEG-3 tallow } \\
\text { aminopropylamine }\end{array}$ & $\begin{array}{l}\text { PEG-3 tallow } \\
\text { aminopropylamine }\end{array}$ \\
\hline Calculated & $400 / 1,567$ & 400 & 800 & 1,600 & 3,134 & 6,268 & 12,536 \\
\hline
\end{tabular}

Concentration (ppm) 
curve) with the Gompertz equation with the "grofit" package in $\mathrm{R}$ statistical software (R Foundation for Statistical Computing, Vienna, Austria) as described earlier [18].

Taking into consideration the average growth rate of biofilm and the correspondence of increase in lag time [roughly a biofilm doubling time] to a $\mathrm{x} 2$ reduction in the bacterial population [25], the reduction in the biofilm population was estimated by using the following approach (1):

Biofilm reduction $(\%)=100-\left(100 / 2^{\wedge}\left(\left(\right.\right.\right.$ lag time $e_{\text {treated sample }}$ -lag time $\left.\mathrm{e}_{\text {control }}\right) /(\ln (2) /$ growth rate control $\left.\left.)\right)\right)$.

\section{Statistical Analysis}

The Shapiro-Wilk test for normality was applied to the samples, differences between mouth rinses and untreated controls were assessed by using Student's $t$-test with significance set to $p<0.05$, and differences between the different concentrations were assessed by a one-way ANOVA using GraphPad Prism (version 7.00 for Mac, GraphPad Software, La Jolla, California, USA, www.graphpad.com).

\section{RESULTS}

Three different parameters (lag time and maximum growth rate, and reduction in active biofilm) were assessed from the IMC data, and they are presented in Table 2.

Dose-dependent reduction in active biofilms was detected for samples treated with increasing concentrations of PEG-3 tallow aminopropylamine; however, no differences $(p>0.05)$ were measured for maximum growth rate at the same time, while statistical differences in LT $(p<0.05)$ were detected. Using concentrations of 400 and $800 \mathrm{ppm}$ tin revealed results similar to meridol mouth rinse (although statistically seen as there were differences found, $p<0.05$ ), while growth was inhibited during the whole detection period of $72 \mathrm{~h}$ when samples were treated with an experimental rinse containing $1,600 \mathrm{ppm}$ tin. Interestingly, when assessing the reduction percentage in active biofilm, only the highest concentration (12,536 ppm) of PEG-3 tallow aminopropylamine revealed comparable results to meridol (55.3\% reduction in active biofilm) and rinses based on $\mathrm{SnF}_{2}$ (43.4\% for $400 \mathrm{ppm}$ tin, $49.9 \% 800 \mathrm{ppm}$ tin, and $>99 \%$ of active biofilm reduction for $1,600 \mathrm{ppm}$ tin) reaching to the average reduction of about $57.5 \%$. Lower concentrations of PEG-3 tallow aminopropylamine showed reductions of $16.9 \%$ for $3,134 \mathrm{ppm}$ and $33.5 \%$ for $6,268 \mathrm{ppm}$. Maximum growth rate was significantly lower for all the samples containing $\mathrm{SnF}_{2}$ than for the samples containing control biofilms $(p<0.05)$; no differences were found between the control and all the PEG-3 tallow aminopropylamine $(p>0.05)$. Samples treated with experimental rinse 3 also revealed no growth after 7 days, allowing the assumption that $>99 \%$ of the active biofilms was eradicated.

The parameters lag time and growth rate both showed high reproducibility rates within the treated groups of biofilms and for the controls; thus, the screening method provided reliable results.

\section{DISCUSSION}

The efficacy of different mouth rinses on plaque control has been analyzed in many studies. Fluorides, which are mainly used to reinforce demineralization, have also shown antimicrobial properties [26] and can affect, for example, S. mutans through various mechanisms [27-29]. This antibacterial effect of $\mathrm{SnF}_{2}$ in cariogenic biofilms can be attributed to the ability of stannous ion to reduce bacterial acidogenicity and glucan production [30], while AmF is shown to inhibit the APTase of S. mutans [31]. Additionally, there is not only the efficacy that makes such fluoride formulations (e.g., $\mathrm{SnF}_{2} / \mathrm{AmF}$ ) so attractive but also there are fewer side effects like cytotoxicity and irritations than in mouth rinses with essential oils or chlorhexidine [32]. Furthermore, regarding resistance development in $S$. mutans strains, $\mathrm{AmF} / \mathrm{SnF}_{2}$ can be used for long term in contrast to chlorhexidine, which should be used only for a limited time [33].

However, the major antimicrobial effect of mouth rinses is achieved through various other agents added to the rinses. Thus,

TABLE 2 | Three different parameters were assessed from IMC data: lag time in h, maximum growth rate in 1/h, and reduction in active biofilm in \% compared to untreated control biofilm.

\begin{tabular}{|c|c|c|c|c|c|c|c|c|}
\hline \multirow[t]{2}{*}{ Parameter } & \multirow[t]{2}{*}{ Untreated control } & \multirow{2}{*}{$\frac{\text { Marketed rinse }}{\text { Meridol }}$} & \multicolumn{6}{|c|}{ Experimental rinses } \\
\hline & & & 1 & 2 & 3 & 4 & 5 & 6 \\
\hline Lag time (h) & $8.55 \pm 0.4$ & $18.9 \pm 2.1^{\star \star}$ & $15.9 \pm 1.0^{\star \star}$ & $17.4 \pm 1.5^{\star \star}$ & $>72^{\star \star}$ & $10.9 \pm 0.6^{\star \star}$ & $13.8 \pm 1.1^{\star \star}$ & $19.5 \pm 2.7^{\star \star}$ \\
\hline Maximum growth rate $(1 / \mathrm{h})$ & $0.078 \pm 0.004$ & $0.066 \pm 0.003^{\star \star}$ & $0.065 \pm 0.003^{\star \star}$ & $0.064 \pm 0.003^{\star \star}$ & $0^{\star \star}$ & $0.074 \pm 0.006$ & $0.076 \pm 0.006$ & $0.072 \pm 0.007$ \\
\hline Reduction of active biofilm (\%) & N/A & $55.3 \pm 7.6$ & $43.4 \pm 4.4^{\star \star}$ & $49.9 \pm 5.6^{\star}$ & $>99^{\star \star}$ & $16.9 \pm 4.2^{\star \star}$ & $33.5 \pm 5.5^{\star \star}$ & $57.5 \pm 8.1$ \\
\hline
\end{tabular}

Seven rinses were examined for their antimicrobial properties containing either tin derived from stannous fluoride (SnF $F_{2}$ and/or PEG-3 tallow aminopropylamine as noted in Table 1. Statistical differences were marked with ${ }^{* *} p<0.0001,{ }^{*} p<0.05$. 
this study examined the susceptibility of $S$. mutans biofilms to different experimental mouth rinses with various concentrations of either tin derived from $\mathrm{SnF}_{2}(400,800$, and 1,600 ppm) or PEG-3 tallow aminopropylamine $(3,134,6,268,12,536 \mathrm{ppm})$ and meridol containing both (400 ppm tin $+1,567$ ppm PEG-3 tallow aminopropylamine). The motivation to use these agents lies within the fact that, although both are widely used in new oral care products, the contribution to the antimicrobial effect of single agents within these products is not always clearly defined. Additionally, screening for the best possible concentration allows designing of more efficient rinses based on these data.

The combination of $400 \mathrm{ppm}$ tin derived from $\mathrm{SnF}_{2}$ and 1,567 ppm PEG-3 tallow aminopropylamine derived from AmF (meridol) is showing comparable results (average of $55.3 \%$ active biofilm reduction) to the experimental mouth rinse containing 12,536 ppm PEG-3 tallow aminopropylamine, reaching a reduction in active biofilm by $57.5 \%$. Rinses containing $\mathrm{AmF} / \mathrm{SnF}_{2}$ have shown antiplaque and also antibacterial effects [34-41]. Furthermore, this formulation is able to influence the streptococcus abundance and lactate production [42] by inhibiting the acid production to the same extent as chlorhexidine [43]. The study by Meurman et al. demonstrated the sensitivity of $S$. mutans to an $\mathrm{AmF} / \mathrm{SnF}_{2}$ solution in vitro. Regarding the topic of cariology, it is mentioned that there are, maybe, some advantages in the usage of $\mathrm{SnF}_{2} / \mathrm{AmF}$ solution compared to chlorhexidine [44].

Additionally, we also found that an increasing concentration of tin $(400,800$, and 1,600 ppm) leads to a decrease in active biofilm and a prolonged lag time. Thus, tin has also an antibacterial effect that is dose dependent. However, the relation between the concentration and the reduction in active biofilm is not proportional. Regarding the active biofilm reduction, more than $800 \mathrm{ppm}$ tin is needed to achieve approximately comparable effects to the $\mathrm{SnF}_{2} / \mathrm{AmF}$ solution. However, the efficacy of rinse 3 containing tin at a concentration of 1,600 ppm was inhibiting the growth of biofilms throughout the detection period; thus, we cannot say whether the whole biofilm was killed, or it would have shown delayed growth after the $72 \mathrm{~h}$. Therefore, for obtaining results for higher antimicrobial concentrations, the metabolic patterns of IMC should be followed for prolonged periods of time. The reduction is achieved through both bactericidal effects as the lag time is prolonged for these samples in comparison with untreated control; thus, a larger proportion of cells was killed in the beginning, as well as bacteriostatic effect as the growth rate is decreased, which means that the bacterial growth was impaired throughout the measurement. This was only to be seen in the treated samples that contained $\mathrm{SnF}_{2}$; the effect of PEG-3 tallow aminopropylamine seems to be only bactericidal as the growth rate is not affected and stays similar to the untreated control biofilm.

Svanberg and Rölla have shown that $S$. mutans counts in plaque and in saliva can be reduced through rinsing with $\mathrm{SnF}_{2}$ and have suspected that this is a possible reason for a decrease in the occurrence of caries. Additionally, one of the tested concentrations of $\mathrm{SnF}_{2}$ (0.2 and $0.4 \%$ ) was comparable to our tested concentration in rinse $3,1,600 \mathrm{ppm}(0.22 \%)$ [45]. The formulation of $\mathrm{SnF}_{2}$ in water-based solutions is challenging because of the diminished stability $[13,46]$. In the formulation $\mathrm{SnF}_{2}$ together with $\mathrm{AmF}$ (meridol), the positive properties of the $\mathrm{SnF}_{2}$ are stabilized. Synergistic effects led to a positive effect in caries prevention and periodontal health through plaque reduction $[13,47]$. The increasing concentration of PEG-3 aminopropylamine shows a proportional ratio to the reduction in active bacteria biofilm. At concentrations of 12,536 ppm, the antibacterial effect is even somewhat higher than in the meridol.

An advantage of using IMC is fast and reliable screening that generates a real-time signal with high sensitivity of the produced heat by microorganisms, and unlike spectrophotometric analyses, it is not affected by the possible turbidity of the solution caused by antimicrobial agents. In addition, the non-destructive property enables the efficient use of this method for biofilms, without disturbing their structure and function $[18,25,48]$, and measuring the extent of antimicrobial effect of solutions on biofilms. However, the biggest limitation of the study is the unknown efficacy of rinses while planning the experiments and being unable to predict how long the detection time should be. Nevertheless, it can be easily overcome by running a test experiment to see how long the samples need for their heat flow curve to return to baseline. Additionally, the study uses water for the dilution of rinses; thus, no precipitation should happen while doing so. Also, here, it can be easily adapted to another solution as long as the rinsing step is carried out with saline before placing the biofilms in the IMC ampoule.

In conclusion, the study revealed that the effect of $\mathrm{SnF}_{2}$, in combination with $\mathrm{AmF}$, is enhanced and mouth rinse also is effective in caries-related biofilm reduction when concentrations of these two agents are low. To achieve a similar effect with $\mathrm{SnF}_{2}$ or PEG-3 aminopropylamine alone, higher concentrations are needed, which, however, might lead to resistance development over time. Thus, the choice of mouth rinse has to be carefully considered based on whether short- or long-term use is planned. Additionally, the study also shows that IMC is a reliable tool to use for future screenings on the efficacy of antimicrobial agents on biofilms as shown earlier [18, 49], providing highly reproducible results throughout the experiment despite possible biofilm variability. However, it is important to adjust the screening period to the efficacy of the rinses in order to obtain a reliable metabolic pattern to assess the growth parameters.

Furthermore, this study introduces a model biofilm combined with a reliable screening method for all future investigations in which the antimicrobial effect of solutions on cariogenic biofilms could be easily assessed; with the big advantage in comparison with many other studies, the biofilm stays intact throughout the whole process and the effect of planktonic cells can be neglected. Thus, various antimicrobial agents or optimization of concentrations and/or combinations of such agents and proportions of concentrations of tin and PEG-3 aminopropylamine can be studied further for their resistance development using this model. 


\section{DATA AVAILABILITY STATEMENT}

The raw data supporting the conclusions of this article will be made available by the authors, without undue reservation.

\section{AUTHOR CONTRIBUTIONS}

OB, TW, and MA-F: conceptualization. $\mathrm{OB}$ and MA-F: methodology and software. JS, OB, TW, and MA-F: validation, data curation, and writing-review and editing. MA-F: formal analysis, project administration, and funding acquisition. JS and MA-F: investigation, writing-original draft preparation, and visualization. TW: resources. TW and MA-F: supervision.

\section{REFERENCES}

1. Lederberg J, McCray AT. Ome sweet 'omics - a genealogical treasury of words genealogical treasury of words. Scientist. (2001) 15:8.

2. Jenkinson HF, Lamont RJ. Oral microbial communities in sickness and in health. Trends Microbiol. (2005) 13:589-95. doi: 10.1016/j.tim.200 5.09 .006

3. Dewhirst FE, Chen T, Izard J, Paster BJ, Tanner ACR, Yu WH, et al. The human oral microbiome. J Bacteriol. (2010) 192:5002-17. doi: 10.1128/JB.00542-10

4. Wade WG. The oral microbiome in health and disease. Pharmacol Res. (2013) 69:137-43. doi: 10.1016/j.phrs.2012.11.006

5. Costerton JW, Geesey G, Cheng KJ. How bacteria stick. Sci Am. (1978) 238:86-95. doi: 10.1038/scientificamerican0178-86

6. Hall-Stoodley L, Costerton JW, Stoodley P. Bacterial biofilms: from the natural environment to infectious diseases. Nat Rev Microbiol. (2004) 2:95108. doi: 10.1038/nrmicro821

7. Seneviratne CJ, Zhang CF, Samaranayake LP. Dental plaque biofilm in oral health and disease. Chin J Dent Res. (2011) 14:87-94.

8. Kassebaum NJ, Smith AGC, Bernabé E., Fleming TD, Reynolds AE, Vos T, et al. Global, regional, national prevalence. incidence, and disability-adjusted life years for oral conditions for 195 countries, 1990-2015: a systematic analysis for the global burden of diseases, injuries, risk factors. J Dent Res. (2017) 96:380-7. doi: 10.1177/0022034517693566

9. Vos T, Allen C, Arora M, Barber RM, Bhutta ZA, Brown A, et al. Global, regional, national incidence, prevalence, and years lived with disability for 310 diseases and injuries, 1990-2015: a systematic analysis for the global burden of disease study 2015. Lancet. (2016) 388:1545602. doi: 10.1016/S0140-6736(16)31678-6

10. Marsh PD. Dental plaque as a biofilm and a microbial community - implications for health and disease. BMC Oral Health. (2006) 6:S14. doi: 10.1186/1472-6831-6-S1-S14

11. Takahashi N, Nyvad B. The role of bacteria in the caries process: ecological perspectives. J Dent Res. (2011) 90:294-303. doi: 10.1177/0022034510379602

12. Tanner ACR, Kressirer CA, Rothmiller S, Johansson I, Chalmers NI. The caries microbiome: implications for reversing dysbiosis. Adv Dent Res. (2018) 29:78-85. doi: 10.1177/0022034517736496

13. Paraskevas S. Randomized controlled clinical trials on agents used for chemical plaque control. Int J Dent Hyg. (2005) 3:162-78. doi: 10.1111/j.1601-5037.2005.00145.x

14. Tartaglia GM, Tadakamadla SK, Connelly ST, Sforza C, Martín C. Adverse events associated with home use of mouthrinses: a systematic review. Ther Adv Drug Saf. (2019) 10:204209861985488. doi: 10.1177/2042098619854881

15. Pessan JP, Toumba KJ, Buzalaf MAR. Topical use of fluorides for caries control. Monogr Oral Sci. (2011) 22:115-32. doi: 10.1159/000325154

16. van der Mei HC, Engels E, de Vries J, Busscher HJ. Effects of amine fluoride on biofilm growth and salivary pellicles. Caries Res. (2008) 42:1927. doi: $10.1159 / 000111746$
All authors have read and agreed to the published version of the manuscript.

\section{FUNDING}

This research was funded by COLGATE-PALMOLIVE EUROPE Sàrl.

\section{ACKNOWLEDGMENTS}

We would like to acknowledge Dr. Ruth Hinrichs, Dr. Svenia Schmid, and Norbert Huber from Colgate-Palmolive Europe Sàrl for this collaboration and for providing the details on the materials used.

17. Quirynen M, Soete MD, Pauwels M, Gizani S, Van Meerbeek B van Steenberghe D. Can toothpaste or a toothbrush with antibacterial tufts prevent toothbrush contamination? J Periodontol. (2003) 74:31222. doi: 10.1902/jop.2003.74.3.312

18. Astasov-Frauenhoffer M, Braissant O, Hauser-Gerspach I, Weiger R, Walter C, Zitzmann NU, et al. Microcalorimetric determination of the effects of amoxicillin, metronidazole, and their combination on in vitro biofilm. $J$ Periodontol. (2014) 85:349-57. doi: 10.1902/jop.2013.120733

19. Wernli L, Bonkat G, Gasser TC, Bachmann A, Braissant O. Use of isothermal microcalorimetry to quantify the influence of glucose and antifungals on the growth of Candida albicans in urine. J Appl Microbiol. (2013) 115:118693. doi: $10.1111 /$ jam. 12306

20. Gysin M, Braissant O, Gillingwater K, Brun R, Mäser P, Wenzler T. Isothermal microcalorimetry - A quantitative method to monitor Trypanosoma congolense growth and growth inhibition by trypanocidal drugs in real time. Int J Parasitol Drugs Drug Resist. (2018) 8:15964. doi: 10.1016/j.ijpddr.2018.03.003

21. Gonzalez Moreno M, Butini ME, Maiolo EM, Sessa L, Trampuz A. Antimicrobial activity of bioactive glass S53P4 against representative microorganisms causing osteomyelitis - Real-time assessment by isothermal microcalorimetry. Colloids Surf B Biointerfaces. (2020) 189:110853. doi: 10.1016/j.colsurfb.2020.110853

22. Tellapragada C, Hasan B, Antonelli A, Maruri A, de Vogel C, Gijón $\mathrm{D}$, et al. Isothermal microcalorimetry minimal inhibitory concentration testing in extensively drug resistant Gram-negative bacilli: a multicentre study. Clin Microbiol Infect. (2020) 26:1413.e1-7. doi: 10.1016/j.cmi.202 0.01 .026

23. Cho SB, Nakanishi K, Kokubo T, Soga N, Ohtsuki C, Nakamura $\mathrm{T}$, et al. Dependence of apatite formation on silica gel on its structure: effect of heat treatment. J Am Ceram Soc. (1995) 78:1769-74. doi: 10.1111/j.1151-2916.1995.tb08887.x

24. Astasov-Frauenhoffer M, Braissant O, Hauser-Gerspach I, Daniels AU, Wirz D, Weiger R, et al. Quantification of vital adherent Streptococcus sanguinis cells on protein-coated titanium after disinfectant treatment. J Mater Sci Mater Med. (2011) 22:2045-51. doi: 10.1007/s10856-011-4377-5

25. Braissant O, Bachmann A, Bonkat G. Microcalorimetric assays for measuring cell growth and metabolic activity: methodology and applications. Methods. (2015) 76:27-34. doi: 10.1016/j.ymeth.2014.10.009

26. Hamilton IR. Biochemical effects of fluoride on oral bacteria. J Dent Res. (1990) 69:660-7. doi: 10.1177/00220345900690\$128

27. Marquis RE. Antimicrobial actions of fluoride for oral bacteria. Can J Microbiol. (1995) 41:955-64. doi: 10.1139/m95-133

28. Koo H. Strategies to enhance the biological effects of fluoride on dental biofilms. Adv Dent Res. (2008) 20:17-21. doi: 10.1177/154407370802000105

29. Buzalaf MAR, Pessan JP, Honório HM, Ten Cate JM. Mechanisms of action of fluoride for caries control. Monogr Oral Sci. (2011) 22:97114. doi: $10.1159 / 000325151$ 
30. Ferretti GA, Tanzer JM, Tinanoff N. The effect of fluoride and stannous ions on Streptococcus mutans. Viability, growth, acid, glucan production, and adherence. Caries Res. (1982) 16:298-307. doi: 10.1159/000260612

31. Van Loveren C. Antimicrobial activity of fluoride and its in vivo importance: identification of research questions. Caries Res. (2001) 35(Suppl. 1):6570. doi: 10.1159/000049114

32. Balloni S, Locci P, Lumare A, Marinucci L. Cytotoxicity of three commercial mouthrinses on extracellular matrix metabolism and human gingival cell behaviour. Toxicol In Vitro. (2016) 34:88-96. doi: 10.1016/j.tiv.2016.03.015

33. Kulik EM, Waltimo T, Weiger R, Schweizer I, Lenkeit K, Filipuzzi-Jenny E, et al. Development of resistance of mutans streptococci and Porphyromonas gingivalis to chlorhexidine digluconate and amine fluoride/stannous fluoridecontaining mouthrinses, in vitro. Clin Oral Investig. (2015) 19:154753. doi: 10.1007/s00784-014-1379-y

34. Brecx M, Netuschil L, Reichert B, Schreil G. Efficacy of listerine, meridol and chlorhexidine mouthrinses on plaque, gingivitis and plaque bacteria vitality. $J$ Clin Periodontol. (1990) 17:292-7. doi: 10.1111/j.1600-051X.1990.tb01092.x

35. Brecx M, Brownstone E, MacDonald L, Gelskey S, Cheang M. Efficacy of listerine, meridol and chlorhexidine mouthrinses as supplements to regular tooth cleaning measures. J Clin Periodontol. (1992) 19:2027. doi: 10.1111/j.1600-051X.1992.tb00640.x

36. Brecx M, Macdonald LL, Legary $\mathrm{K}$, Cheang $\mathrm{M}$, Forgay $\mathrm{MG}$. Long-term effects of meridol and chlorhexidine mouthrinses on plaque, gingivitis, staining, bacterial vitality. J Dent Res. (1993) 72:1194-7. doi: 10.1177/00220345930720080601

37. Zimmermann A, Flores-de-Jacoby L, Pan P, Pan P. Gingivitis, plaque accumulation and plaque composition under long-term use of meridol. J Clin Periodontol. (1993) 20:346-51. doi: 10.1111/j.1600-051X.1993.tb00371.x

38. Netuschil L, Weiger R, Preisler R, Brecx M. Plaque bacteria counts and vitality during chlorhexidine, meridol and listerine mouthrinses. Eur J Oral Sci. (1995) 103:355-61. doi: 10.1111/j.1600-0722.1995.tb01857.x

39. Arweiler NB, Netuschil L, Reich E. Alcohol-free mouthrinse solutions to reduce supragingival plaque regrowth and vitality. A controlled clinical study. J Clin Periodontol. (2001) 28:16874. doi: 10.1034/j.1600-051x.2001.028002168.x

40. Auschill TM, Hein N, Hellwig E, Follo M, Sculean A, Arweiler NB. Effect of two antimicrobial agents on early in situ biofilm formation. J Clin Periodontol. (2005) 32:147-52. doi: 10.1111/j.1600-051X.2005.00650.x

41. Weiland B, Netuschil L, Hoffmann T, Lorenz K. Substantivity of amine fluoride/stannous fluoride following different modes of application: a randomized, investigator-blind, placebo-controlled trial. Acta Odontol Scand. (2008) 66:307-13. doi: 10.1080/00016350802310947

42. Fernandez y Mostajo M, Exterkate RAM, Buijs MJ, Crielaard W, Zaura E. Effect of mouthwashes on the composition and metabolic activity of oral biofilms grown in vitro. Clin Oral Invest. (2017) 21:122130. doi: 10.1007/s00784-016-1876-2

43. Damen JJM, Buijs MJ, ten Cate JM. Acidogenicity of buccal plaque after a single rinse with amine fluoride - stannous fluoride mouthrinse solution. Caries Res. (2002) 36:53-7. doi: 10.1159/000057591

44. Meurman JH, Jousimies-Somer H, Suomala P, Alaluusua S, Torkko $\mathrm{H}$, Asikainen S. Activity of amine-stannous fluoride combination and chlorhexidine against some aerobic and anaerobic oral bacteria. Oral Microbiol Immunol. (1989) 4:117-9. doi: 10.1111/j.1399-302X.1989.tb0 0109.x

45. Svanberg M, Rölla G. Streptococcus mutans in plaque and saliva after mouthrinsing with $\mathrm{SnF}_{2}$. Scand J Dent Res. (1982) 90:292-8. doi: 10.1111/j.1600-0722.1982.tb00740.x

46. Van der Weijden FA, Van der Sluijs E, Ciancio SG, Slot DE. Can chemical mouthwash agents achieve plaque/gingivitis control? Dent Clin North Am. (2015) 59:799-829. doi: 10.1016/j.cden.201 5.06 .002

47. Hellwege KD. Die Praxis der Zahnmedizinischen Prophylaxe: Ein Leitfaden für die Individualprophylaxe, Gruppenprophylaxe und Initiale Parodontaltherapie. Stuttgart: Georg Thieme Verlag (2003). doi: 10.1055/b-002-7274

48. Braissant O, Wirz D, Göpfert B, Daniels AU. Use of isothermal microcalorimetry to monitor microbial activities. FEMS Microbiol Lett. (2010) 303:1-8. doi: 10.1111/j.1574-6968.2009.01819.x

49. Astasov-Frauenhoffer M, Braissant O, Hauser-Gerspach I, Daniels AU, Weiger $\mathrm{R}$, Waltimo $\mathrm{T}$. Isothermal microcalorimetry provides new insights into biofilm variability and dynamics. FEMS Microbiol Lett. (2012) 337:317. doi: 10.1111/1574-6968.12007

Conflict of Interest: This research was funded by COLGATE-PALMOLIVE EUROPE sàrl. The funders had no role in the design of the study; in the collection, analyses, or interpretation of data; in the writing of the manuscript, or in the decision to publish the results.

The authors declare that the research was conducted in the absence of any commercial or financial relationships that could be construed as a potential conflict of interest.

Copyright (c) 2021 Steiger, Braissant, Waltimo and Astasov-Frauenhoffer. This is an open-access article distributed under the terms of the Creative Commons Attribution License (CC BY). The use, distribution or reproduction in other forums is permitted, provided the original author(s) and the copyright owner(s) are credited and that the original publication in this journal is cited, in accordance with accepted academic practice. No use, distribution or reproduction is permitted which does not comply with these terms. 